\title{
Settlement Archaeology in Southern Scandinavia. Preconditions and Prospecting Methods
}

\section{Jes MARTENS}

\begin{abstract}
Iron Age (500 BC-1000AD) settlements have been excavated in large numbers in Denmark and Scandinavia, and not only the houses but the layout of the farms and villages are well illuminated themes. Since this is not the case everywhere in Europe, this paper focuses on the important first step in order to get to grips with this problem; the archaeological prospecting. There are a number of methods at hand and they work best in combination. While prospecting, the archaeologist has to work in a source critical manner in order not simply to reproduce already known facts.
\end{abstract}

Keywords: field surveying, settlement archaeology, source criticism, field archaeological methods.

\section{Introduction}

The notion "settlement archaeology" may have many interpretations - one is Gustaf Kossinna's "Siedlungsarchäologische Methode” (Kossinna 1911) - another is the actual excavation of settlements. Though the former method has been applied in Scandinavian archaeology, it is the latter that the region is most known for. While the first method deals with general patterns and quite often - especially in the early days - bases on indirect sources such as stray finds, burials etc., the latter is dealing with specific settlements. The definition of "settlement" is at play here, since in the first case "settlement" is understood on a general level as the area one moves in, lives in, produces in, performs rituals in, gets buried in etc, while the latter focuses on the actual dwelling sites. Thus there is no good and bad in the distinction, since the two points of departure are complementary and both are needed in order to get a deeper comprehension of prehistoric settlement. The methods are, however, quite often applied independently, and it is not uncommon to see studies about prehistoric settlements without a single settlement plan, or publications of a particular settlement without reference to the general settlement pattern. It is not the purpose of this paper to dig any further into this matter, but just to bring the attention to the problem; both points of departure are necessary in order to understand "settlements". Since Iron Age settlements are not equally well-known in every region of Northern Central Europe, the focus will be on how to localize settlements, taking outset in the Scandinavian archaeology. 
Settlement Archaeology in Scandinavia - a brief history of research

It is no coincidence that Scandinavian and Danish settlement archaeology had an early start since the area offers or at least (before the 20th century) offered great preservation conditions. Thus traces of Iron Age settlements in certain regions were preserved as ruins visible in the landscape (fig. la-b). It was, however, not until the 1880 'es that these ruins were recognized as remains of prehistoric houses, and this first happened on Gotland (Nordin 1886). Later, similar finds were found on Öland, in some region of mainland Sweden, in Jutland (Hatt 1938) and in South-Western Norway (Shetelig 1909). Especially in Jutland these sites were under threat of destruction by cultivation and most of them are erased today, at least as sites with visible structures on the surface. The interesting part is that in Denmark the first house sites recognized as such were in fact not preserved as fossil ruins, but were uncovered during the excavation of an Iron Age cemetery at Kraghede in 1906 (Martens 2001). It was only later that the focus moved to fossil settlements in Jutland, but the Kraghede case demonstrated that settlements could be found even when nothing was preserved on the surface. Another lesson that could be learned from this discovery was that if one wanted to observe houses, one needed to open more than a few square meters at a time, since these buildings measured up to $6 \times 15$ meters.

It was therefore in Jutland that the next steps were being made, moving away from excavating settlements with preserved fossil remains towards ploughedover settlements where only the traces of dug-in structures were found. This also led to the first total surface stripping of settlements (Trelleborg, West Zealand, 1935-1940 (Nørlund 1948), Borremose, North Jutland 1940-1945 (Martens 1994)), where not only the house but also the space between them was stripped. In 1961, C. J. Becker took the next step, moving from manual to
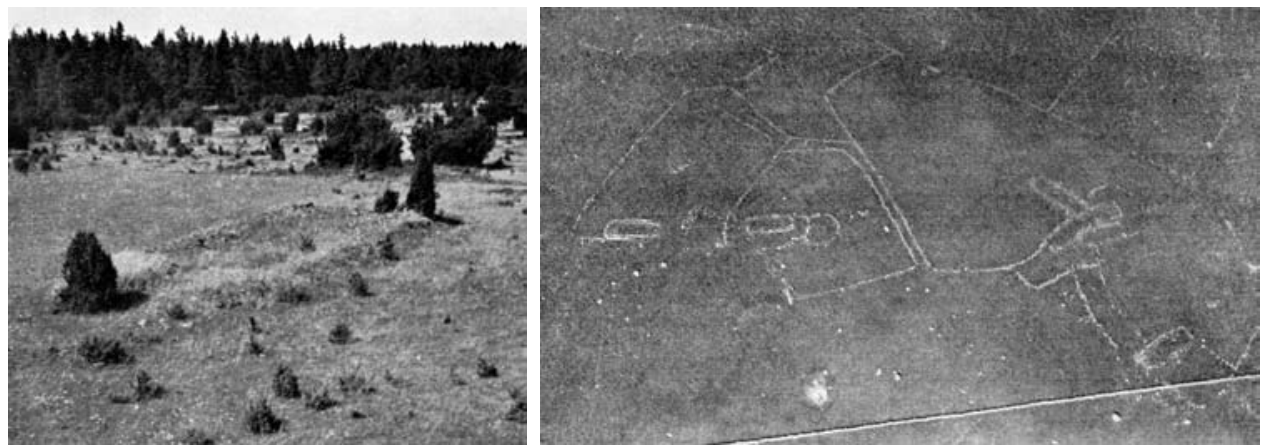

Fig. 1. Fossil Iron Age houses in Scandinavia.

1a. House 18 at Vallhagar, Gotland, before excavation, after Gejvall 1955, fig. 70.

1b. Iron Age houses and enclosed fields seen from the air at Valsnäs, Öland, after Stenberg 1933, fig. 2. 


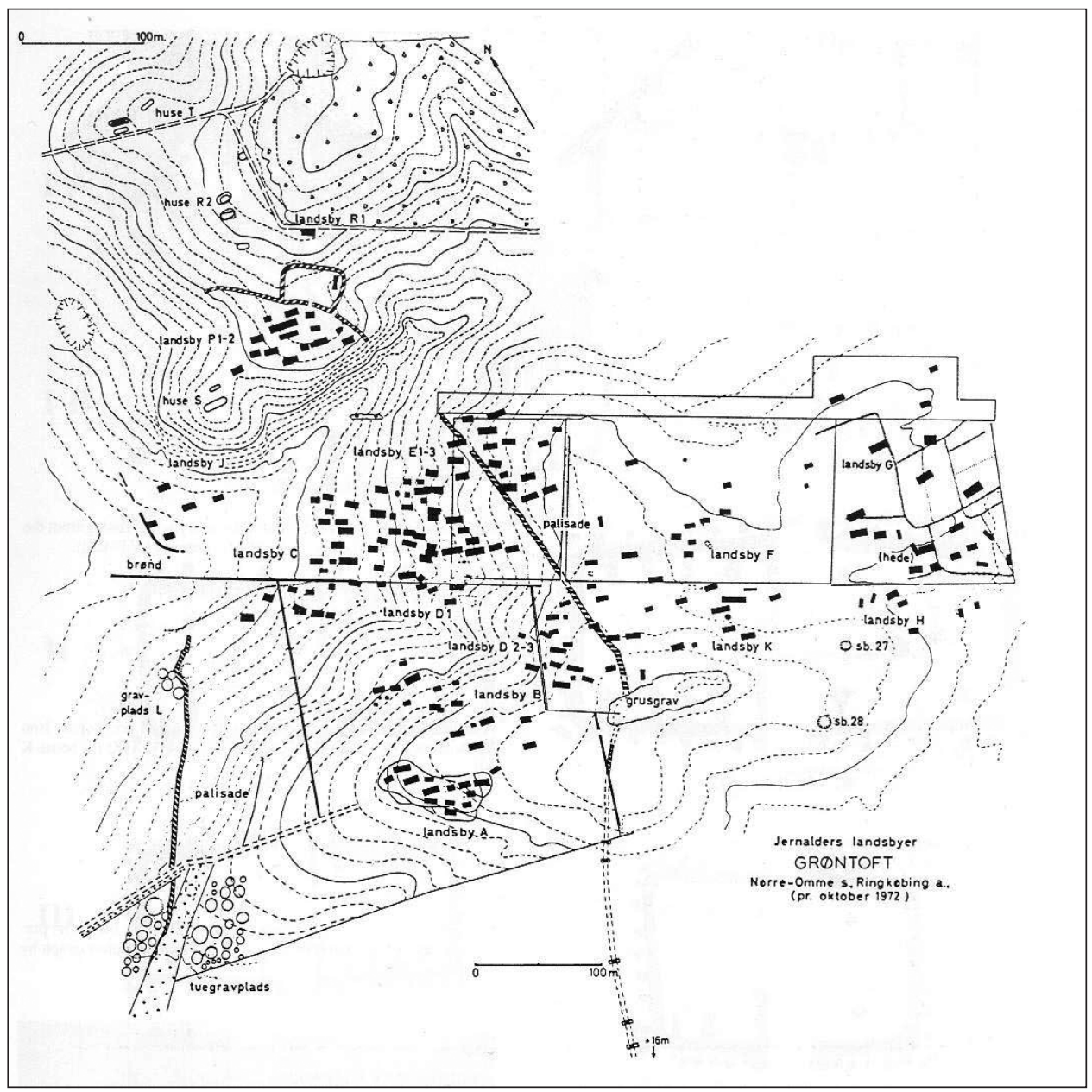

Fig. 2. Plan of the excavated area at Grøntoft, West Jutland, after Becker 1987, fig. 5.

mechanical surface stripping when he was excavating at Grøntoft in West Jutland (Becker 1965). Here a total surface of $160.000 \mathrm{~m}^{2}$ was unearthed, uncovering a settlement cluster, burial grounds, defence structures and field systems, giving "landscape archaeology" a new meaning (fig. 2). The Grøntoft excavations were such a success that mechanical surface stripping was soon applied by most Danish and later other Scandinavian archaeologists (fig. 3). In spite of this, it took some time before the results could be replicated. The reasons for this are many, but lack of experience with excavating houses without visible remains on the surface and lack of general experience with surface-stripping and documentation are among these.

Mechanical surface stripping is based on the assumption that the topsoil is without importance for the understanding of the investigated site. This has been 

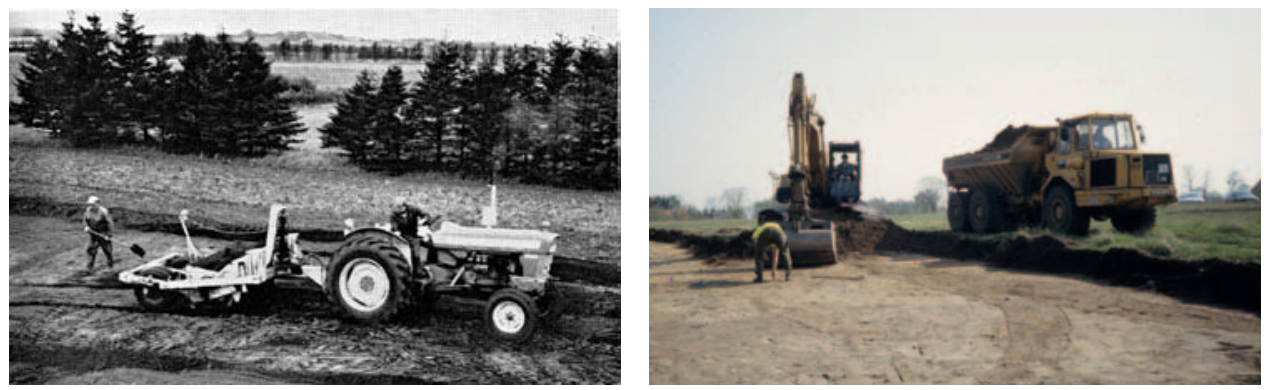

Fig. 3. Mechanical stripping of top soil.

3a. The method originally introduced at Grøntoft, after Becker 1971, fig. 1.

$3 \mathrm{~b}$. Today the topsoil is removed by an excavator that does not drive on the cleaned surface, photo by the author.

proved wrong in several instances during the last decades, especially since the spread of the metal detecting hobby. In many instances finds have been made in the stripped-off soil that must have had some relation to the uncovered dug-in structures. If these finds had been found and registered in the surface soil before the stripping had been done, it might have been possible to connect the finds with the structures. Unfortunately this is rarely the case. But investigations show that on settlements especially from the later part of the Iron Age, metal finds are more likely to be found in the topsoil than in the dug-in structures (Jensen 1986; Svensson \& Söderberg 2009). The first indications of this came during the 1980's, but still today mechanical soil stripping is the dominant excavation method in Scandinavia. The reason is that dealing with the topsoil is a very time and work consuming task and therefore often outside the economical possibilities of modern archaeology. But in many instances the sites are checked by metal detectors before excavation, and samples of the topsoil are sieved.

During the late 1990's and the first decade of the new millennium, Scandinavian settlement archaeology experienced a further "revolution" - full application of natural sciences. These sciences had to some extent been applied before, but never to a larger extent within what is often called "rescue archaeology" due to very tight budgets. From the 1990's onwards this has changed, as it has been recognized that "rescue archaeology" is the major producer of new archaeological knowledge, and today it is expected that a "rescue excavation" in Scandinavia is producing up- to-date data by means of up-to-date methods and strategies. This is getting steadily more important since the cultural heritage, especially in the more densely populated parts of the region, is under perpetual threat of deterioration due to cultivation, draining and the like.

Today the typical dwelling house of the Iron Age is known from most parts of Scandinavia, as are many types of outhouses and buildings with special pur- 
poses (Martens 2011). Furthermore, total settlement plans are known, enabling not only identification of the smallest community unit, i.e. the "family", but also the size and structure of the core social unit, i.e. the "village" upon which the next level of the society may build. Without such information it would be hard to discuss living conditions, organization of family, society, production etc. on more that a theoretical level.

\section{Archaeological Prospecting Methods in Scandinavia}

A precondition for a good excavation result is that one knows where to find what one is looking for and has a good idea of what one expects to find before starting to excavate. This would help choosing the optimal methods and to dimension the investigation. In order to get to that point, a good archaeological prospecting is a precondition. There are several different methods on the market, and one can divide them into several different categories, but here I will choose to review them in the order they would come to use in or be relevant to a hypothetical rescue archaeological project. In modern Scandinavian archaeology, many of these methods are used in combination and at different stages in the preparation of an archaeological project.

\section{Archive stage:}

The preparation for a new archaeological project usually starts in the archive. Apart from checking up on what has been found in the area before, there are a number of options available.

\section{Old maps and place names:}

Old maps, especially the cadastral maps made during the period of enclosure (late 18th century) have proved to be a source of invaluable information concerning the land use during the Late Iron Age (5th - 10th century AD) (Jeppesen 1979; Hansen 2009). On the more detailed maps every single field has its own name, and these names may tell about past locations of settlements or barrows no longer visible. For a long time, the settlement of the Late Iron Age evaded the archaeologists, and therefore this was an important discovery. Even old paintings and drawings may be of some use as a source to prehistoric monuments, although these kinds of sources must be treated with caution.

Aerial photography (ortophotos, satellite photos):

At least since the 1950's the Scandinavian countries have been systematically photographed every 5 th year for the purpose of accurate mapping. These 
vertical photos - called "basic cover" or ortophotos are taken at a specific height, and usually at a time of year when the crops are not yet covering the fields (fig. 4a). In an open agricultural landscape like the Danish this is ideal for the archaeologist, since these photos are in a relatively high quality and it is therefore possible to detect traces of larger structures on them. They have proven invaluable in the search for Iron Age field systems and fortifications (Sørensen 1982; Martens 2006b; 2008). Unfortunately, the EU-demand for green fields during winter times has decreased the value of the later years of these photographs, but it is worthwhile consulting the earlier ones. It is important to note that it is advisable to consult more than one year of these ortophotos, since for some reason, most likely the weather, it may be different structures that may be visible in different years.

In recent times, satellite photos have been used experimentally. On such photos only the largest structures can be detected in the usual way, but the photos offer opportunities to look at the chemical spectrum of the soil.

\section{Farmers' Phosphate Mapping:}

In the early 20th century, Olof Arrhenius discovered that there is a relation between prehistoric/historic settlement and phosphate rich soil (Arrhenius 1935). This he did on base of a soil mapping made for the sugar beet factories in Sweden, and this map is in use until this day. In Denmark the farmers keep track on the level of phosphate in their fields in order to optimize the yield of the fields. Lars Jørgensen has demonstrated that when collected from a larger area, these data may, like in Sweden, be used to localize settlements and other phosphate producing sites (Jørgensen et al., 1992). The setback here is that not all types of prehistoric settlements did produce high values of phosphate (Hartman 1990; Martens 2006a).

\section{Stray Finds:}

Stray finds may be indicative of what kinds of monuments one may expect in a certain area, but this source has its flaws too. The archaeological record may be biased due to the existence or lack of local archaeologists or interested private collectors and their personal preferences. And besides, some periods and types of monuments leave a lot of artefacts to find, while other types do not. In the case of the Scanian West Coast Rail Road project there were almost no indication of Iron Age settlements (500 BC-500 AD) in the area before the project started, but by the end of the project, every third site in the area could be dated to this period. 

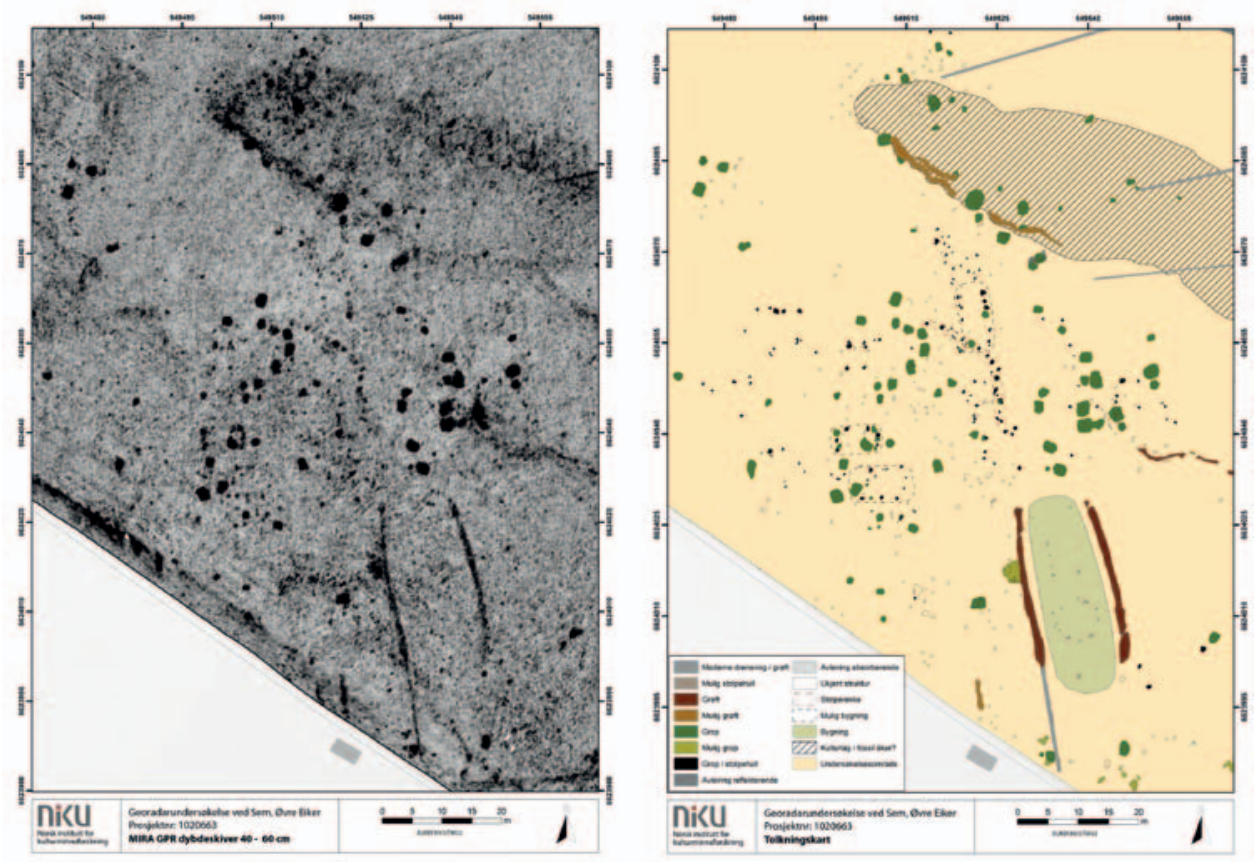

Fig. 4. Aerial photography

4a. Ortophotos with Celtic fields at Langholt, North Jutland, after Sørensen 1982, fig. 5.

4b. Aerial photograph of cropmarks of plough-over barrow cemetery at Gulli, Vestfold, photo by Dagfinn Skre. This cemetery which was later excavated could not be detected by GPR and magnetometer (Gjerpe 2005, 160).

\section{Predictive methods:}

Since archaeology in most countries today is carried out in advance of development projects, it has become an increasing demand that we should develop and improve predictive methods and tools. Predictive methods may be helpful if one aims at calculating population density and the like in an area, but as a tool for planning archaeological investigations it has its drawbacks. First and foremost it reproduces already known knowledge, while the unknown and unexpected remains so (Klitgaard 2001). Therefore predictive methods should only be used with the greatest caution if at all, when asserting the amount of cultural heritage in an area prior to an archaeological investigation.

\section{Topography}

This particular type of predictive method is often used in archaeology. As stated above it is a method which is useful for finding new sites of the same character one already knows. while it does not help in the search for structures 

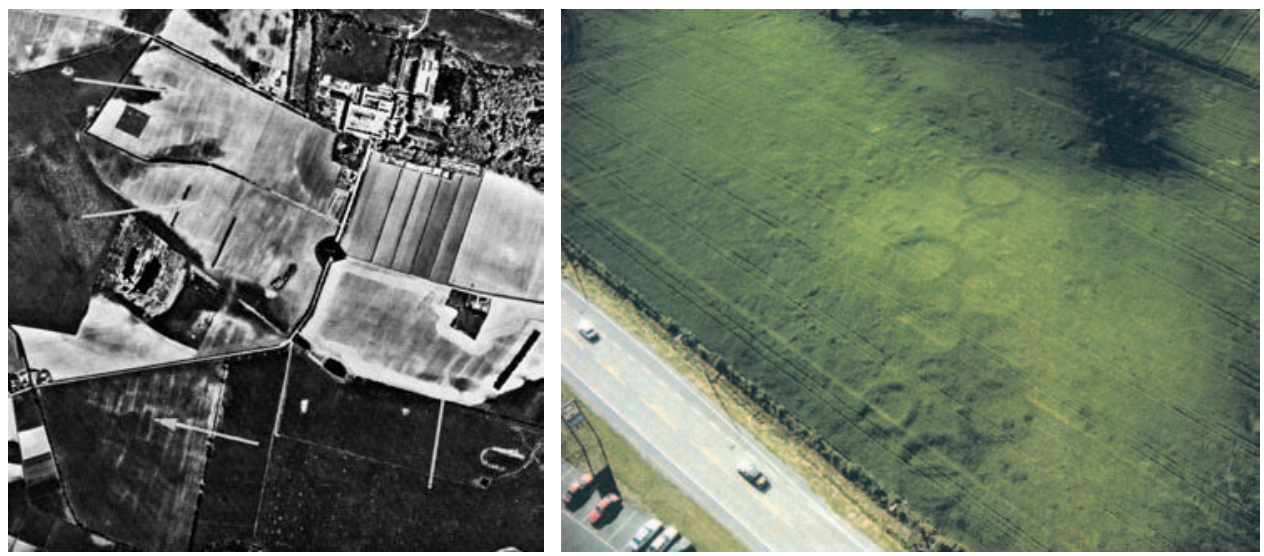

Fig. 5. Lidarscan, cut out of the national LIDAR-scan of Denmark showing a fossil landscape with barrows, celtic fields and hollow ways at Lundby hede and Gundersted hede, North Jutland, source: www.miljoegis.mim.dk/spatialmap?

and sites of hitherto unknown types. Therefore even this method should never stand alone.

\section{Non-intrusive field stage:}

When the archival research is over, what has been achieved is not an indication of what one may find in the field, but an indication of the antiquarian activity in the area prior to the actual project. It is therefore time to start making ones own independent observations, and these ought to be critical to the already existing archaeological record.

\section{Aerial photography (flyovers):}

Aerial photography is a useful method to get a general view over an area and its archaeological potential. In naked fields. colour differences in the soil may indicate archaeological structures, and in ripening fields. crop marks may do the same (fig. $4 \mathrm{~b}$ ). Depending on the soil, the time of year, the weather, the crop and the flying altitude. structures even down to the size of postholes may be seen from the air (Voss 1960; Olesen \& Mauritzen 2015). While this may be a very rewarding method when successful, a negative result may mean nothing more than that one or more of the necessary preconditions were not optimal.

\section{LIDAR:}

LIDAR-scanning is a promising method that has recently become available to archaeology. In Norway it has been applied successfully in the prospecting of vast forested areas with rocky ground (Risbøl 2009; Risbøl et al. 2013). In Denmark the ministry of environment has published a complete scan of the 
country (fig. 5) on the internet (www.miljoegis.mim.dk/spatialmap?). This has been used to identify fossil traces of Iron Age field systems in areas covered by forest and heather (Nielsen 2010; Nielsen \& Clemmesen 2015). This kind of work would earlier have costed considerable man-power and time, while at the same time many of the structures would have escaped notice because their extent is too large and too indistinct to be visible on the ground.

\section{GPR and Magnetometer:}

These two ground penetrating methods have been tried out on several occasions with mixed success. Sometimes they have provided accurate information about the monuments hidden in the ground (Kristiansen et al. 2016; Stamnes 2016), in other instances the results have been misleading. Apparently soil types as well as electric lines and other factors may interfere, what essentially means that a negative result cannot be trusted. The method for instance failed to capture the traces form a ploughed over Viking Age cemetery at Gulli in Vestfold (Gjerpe 2005, 160), though it was visible as crop marks (fig. 4b). But used in conjunction with other methods, GPR and magnetometer scanning may under the right circumstances provide very useful information for planning an excavation (fig. 6).

\section{Field survey:}

Field walking is the most traditional method to find prehistoric and historic sites. In cultivated land one may look for artefacts, burned stones and ploughed-up ashes, while in areas covered by heather and forest one may look for pits, ditches, walls, hollow ways etc. The problem

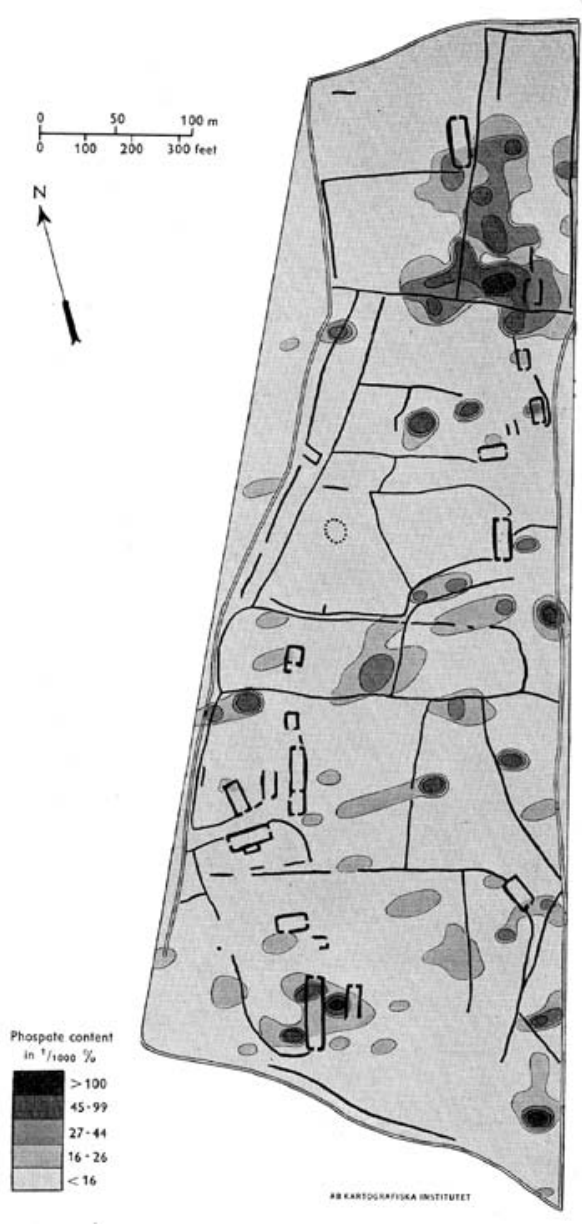

Fig. 6. GPR-scanning showing a house and an area with pits at Sem in Øvre Eiker, Buskerud, left the scan, right the interpretation, after Kristiansen et al. 2016, fig. 17 and 21. 
with this method is that not all periods or types of monuments leave such traces behind (Jacobsen 1984; Henriksen 1992). In Danish archaeology, settlements from the Bronze Age and later Iron Age for long evaded discovery since the only way to prospect was field walking. This method is therefore today only used as a supplement to other more efficient methods. It may, however, still have relevance in cases of monitoring the development of preservation of a known site.

\section{Intrusive field stage}

\section{Metal detecting}

Metal detecting became popular as a hobby in Denmark during the late 1970's and after a few years and spectacular finds, the antiquarian authorities decided to accept the hobby as a positive addition to the numerous hobby archaeologist already collecting artefacts on the fields and reporting them to the museums (Thrane 1984; Martens \& Ravn (eds) 2016). Ever since, metal detecting has offered valuable extra information about sites being excavated, information that otherwise would have been lost in the topsoil that is being stripped away before the excavations start. Metal detecting has also proven an important supplement to ordinary field surveying, since the metal artefacts often come from other periods than other types of artefacts like pottery or flint. In Scandinavia the sites become metal rich from the migration period onwards, and these periods were particularly difficult to find by ordinary surveying

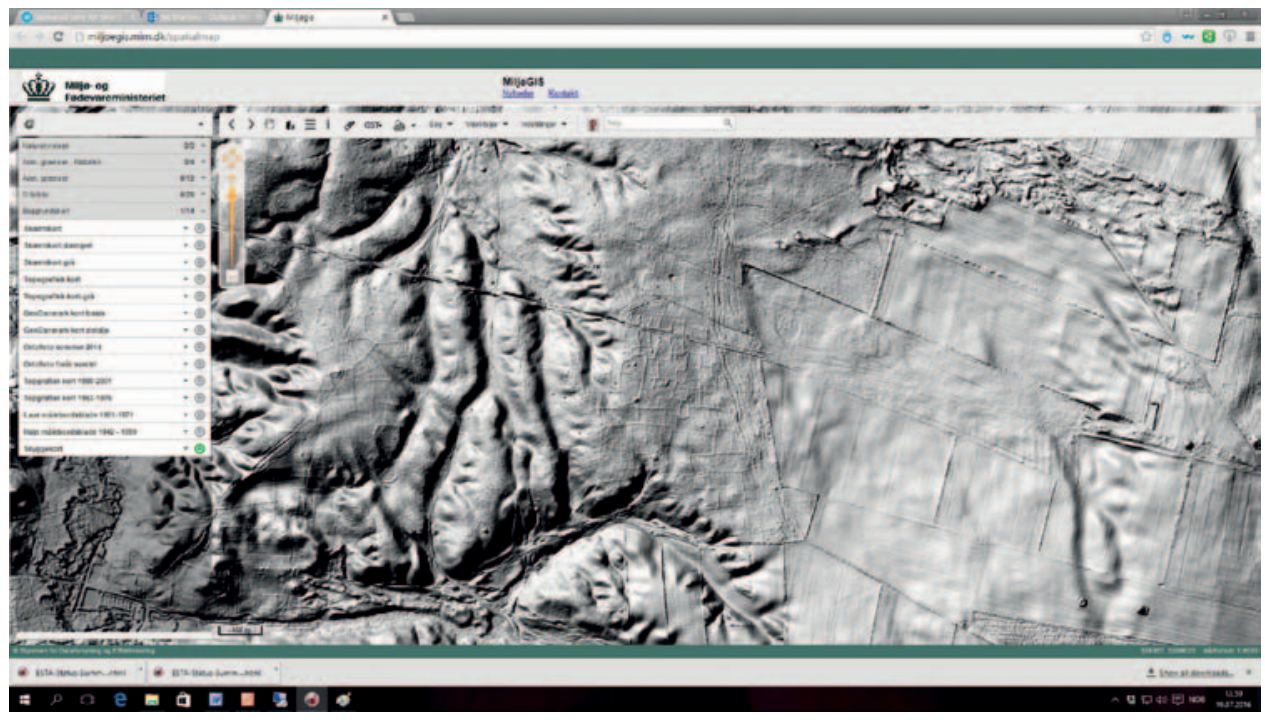

Fig. 7. Phosphate mapping of the Iron Age settlement at Valhagar, Gotland. Notice that the phosphate concentrations are not found inside but close to the buildings, after Arrhenius 1955, fig. 448. 
methods. In Sweden where the private use of metal detectors in the search for archaeological material is forbidden, this has led to the archaeologists carrying out similar searches with metal detectors in advance of excavations.

\section{Phosphate mapping /soil chemistry}

Phosphate mapping has also been applied actively in archaeological prospecting in Scandinavia. The results are mixed, and one can conclude that a negative result does not rule out the possibility of prehistoric settlements (Hartman 1990; Martens 2006a). One of the flaws of the method is that it only seems to catch some periods on some types of monuments, so it is not a method recommended as a stand-alone. Besides it is not always the centre of the settlements that come out with high values as the classic example from Vallhagar on Gotland (Arrhenius 1955) demonstrates (fig. 7).

\section{Sample excavation}

Sample pit excavation is a method commonly used in Norway in forested or rocky terrain. The principle is that a grid is laid out over the area under investigation, and square pits of $0.5 \times 0.5 \mathrm{~m}$ are dug up and the fill sieved in order to find artefacts. Often the localization of the pits will be chosen after a predictive method basing on topography. It is mainly used in order to catch Stone Age sites, but it may also detect sites from other periods. It is obvious that this method is only useful when looking for areas with artefacts, while areas with few artefacts but larger structures will not be detected.

\section{Trenching}

The by far most successful and most widespread prospecting method in Scandinavian archaeology today is mechanical trenching (fig. 8). The top soil is stripped off in long, narrow, parallel trenches, the optimal width being 2-4 meters, and distance between the trenches being 12-15 meters. Originally trenching was used in combination with predictive methods like topography, but during recent years the trenches have been laid out systematically, since it has been realized that this is the only way to discover new types of sites or sites at unexpected locations. Another thing that has been noted is that in the areas of long houses, the orientation of the trenches is not without importance. If the trenches are laid out in a way that would be parallel to the general orientation of the houses, the chance of discovering them diminishes radically, so in fact the best way is to lay them out diagonally (Fonnesbech-Sandberg et al. 1991). But it is not only long houses one is looking for. In an undulating landscape it would be optimal to orientate the trenches at straight angles to the hill sides. Since the 


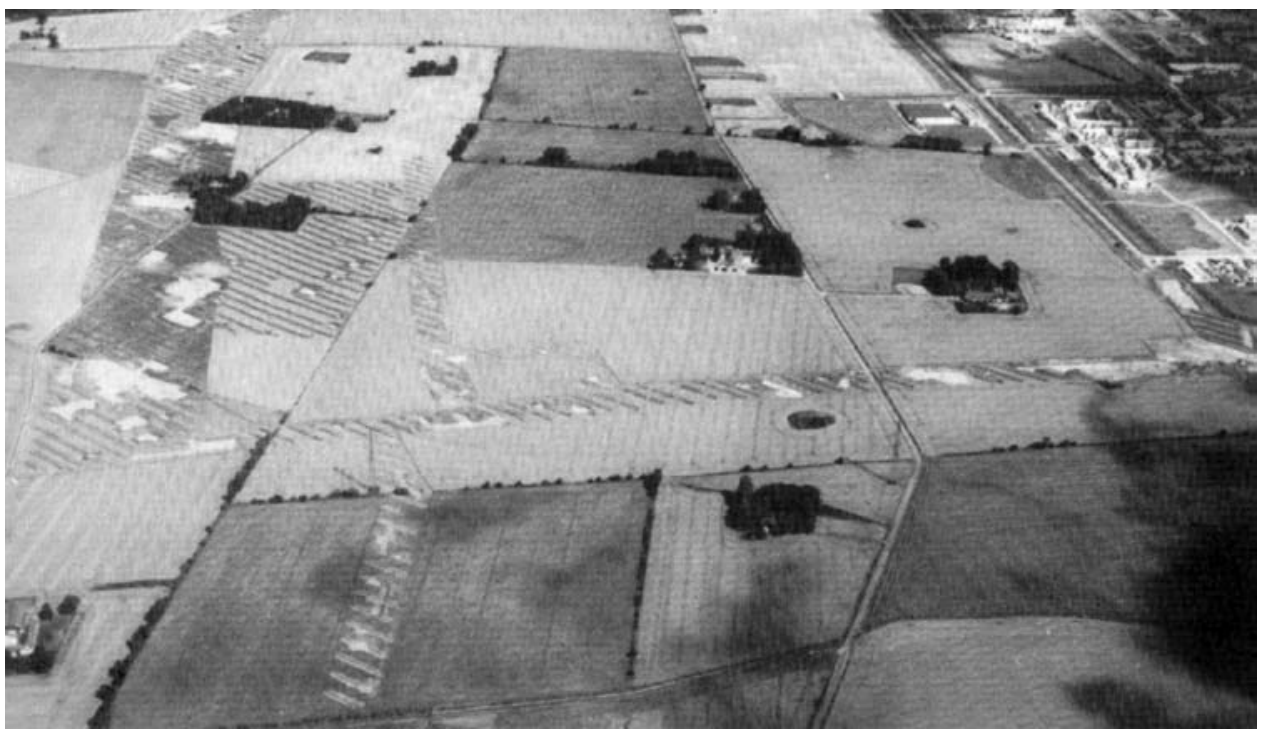

Fig. 8. Trenching at Høje Tåstrup, West of Copenhagen, after Fonnesbech-Sandberg et al. 1991, fig. 1.

chance of detecting field boundaries hereby would increase. Earlier, mechanical stripping was confined to open landscapes, but today it is equally used in forested areas, where it is possible to excavate between the roots of the trees.

\section{Landscape stripping}

As a final method I will include and advocate for landscape stripping. It is a method that is reasonable and useful in connection with most development projects, since the developer will usually strip the topsoil off the land anyway, so why not let the archaeologists do the job. This method, which has been applied in the municipality of Malmö, Sweden, has the advantage that the archaeologist gets a total view of the traces of Prehistoric activity in the area in question before planning and dimensioning the excavation project. The drawbacks are few, the major one being that if time passes between stripping and excavation, erosion and growth may disturb the unearthed monuments.

\section{Conclusion and recommendations}

Above I have listed 15 different archaeological prospecting methods. Of these, the single most successful method and the only one that could stand alone is the trenching, but even this method has its shortcomings and wins in combination with other methods.

In a project in the Norwegian landscape Vestfold, I applied four teams with different specialities; one team specialized on finding Stone Age settlements, 
another specialized in Prehistoric agrarian settlements, a third specialized in Medieval rural settlement and finally a metal detecting team. The four teams surveyed the area independently and their results were to a great deal complementary to each other, partly because you find what you are looking for, partly because the detection of the different kinds of monuments demands different methods (Martens 2009). The results were remarkable, many monuments were found in areas where they hitherto had not been detected, shedding a new light on the Prehistoric use of the landscape, and the number of Iron Age houses from the area was increased considerably (Gjerpe 2008).

Prospecting is one of the most important stages in archaeological research since it to a great degree is shaping the future archaeological record on which we will be basing our research. As this survey shows, many methods may give valuable information if successful, but most often negative results must be treated with caution. Consequently, the best advice is to use several methods in combination, and to do thisin a source critical manner challenging already known facts and patterns.

\section{Bibliography:}

Arrhenius, Olof. 1935. “Markundersökning och arkeologi”. Fornvännen 1935: 65-76.

Arrhenius, Olof. 1955. "The Iron Age Settlements on Gotland and the Nature of the Soil”. In In Valhagar - a Migration Period Settlement at Gotland, edited by Mårten Stenberger and Ole Klindt-Jensen: 1053-1064. Copenhagen: Ejnar Munksgaards Forlag.

Becker, Carl Johan. 1965. "Ein früheisenzeitliches Dorf bei Grøntoft, Westjütland”. Acta Archaeologica vol. XXXVI: 209-222.

Becker, Carl-Johan. 1987. "Farms and Villages in Denmark from the Late Bronze Age to the Viking Period”. In Proceedings of the British Academy vol. LXXIII: 69-96.

Becker, Carl Johan. 1971. "Früheisenzeitliche Dörfer bei Grøntoft, Westjütland”. Acta Archaeologica vol. XLII: 79-110.

Fonnesbech-Sandberg, Eliza, Svend Jensen, and Svend Stokholm. 1991. "Prøvegravninger i forbindelse med bebyggelsesundersøgelser." Arkceologiske Udgravninger i Danmark 1991: 43-56.

Gejvall, Niels-Gustaf. 1955. "Building 18”. In Valhagar - a Migration Period Settlement at Gotland, edited by Mårten Stenberger and Ole Klindt-Jensen: 213226. Copenhagen: Ejnar Munksgaards Forlag.

Gjerpe, Lars-Erik (editor). 2005. Gravfeltet på Gulli, Varia 60. Oslo: Kulturhistorisk museum. 
Gjerpe, Lars-Erik (editor). 2008. Kulturhistoriske, metodiske og administrative erfaringer. E18-prosjektet Vestfold. Bind 4, Varia 74. Oslo: Kulturhistorisk museum.

Hansen, Gitte. 2009. "Middelalderen på landsbygda, status, forvaltning og fremtid i Bergens Museums forvaltningsdistrikt”. In Den tapte middelalder? Middelalderens sentral landbebyggelse, Varia 71, edited by Jes Martens, Vibeke Vandrup Martens and Kathrine Stene. 71-79. Oslo: Kulturhistorisk Museum.

Hartmann, Niels. 1990. "Fosfatanalyse og dens anvendelse som alternativ rekognosceringsmetode”. Arkeologiske Udgravninger i Danmark 1990: 39-46.

Hatt, Gudmund. 1938. "Jernaldersbopladser i Himmerland". Aarbøger for nordisk Oldkyndighed og Historie 1938: 119-266.

Henriksen, Mogens Bo. 1992. "Anvendelsen af rekognoscering som inventeringsmetode ved bebyggelseshistoriske undersøgelser”. Arkæologiske Udgravninger i Danmark 1992: 32-48.

Jacobsen, Jørgen A. 1984. "A Contribution to the Evaluation of Archaeological Field-Surveying." Journal of Danish Archaeology vol. 3: 187-198.

Jensen, Stig. 1986. "Pløjelagsarkæologi”, Arkeologiske udgravinger i Danmark 1986: 9-19.

Jeppesen, Torben Grøngaard. 1979. "Bebyggelsesflytninger på overgangen mellem vikingetid og middelalder”. In Landsbyens opståen. Indledende studier over middelalderlandsbyernes pladskontinuitet. Skrifter fra historisk institut, Odense Universitet, nr. 24, edited by Torben Grøngaard Jeppensen: 99-117. Odense: Odense Universitet.

Jørgensen, Lars, Finn-Ole Nielsen, and Palle Ø. Sørensen. 1992. "Jordbundsanalysekort og forhistorisk bosættelse”. Arkcoologiske Udgravninger i Danmark 1992: 21-31.

Klitgaard, Sussanne. 2001. "Arkæologiske forundersøgelser - metode, økonomi og resultat”. Arkeoologiske Udgravninger i Danmark 2001: 5-25.

Kossinna, Gustaf. 1911. Die Herkunft der Germanen. Zur Methode der Siedlungsarchäologie. Würzburg: Kabitzsch.

Kristiansen, Monica, Erich Nau and Lars Gustavsen. 2016. Georadarundersøkelse ved Sem gård (73/3), Øvre Eiker kommune, Buskerud fylkeskommune. Sluttrapport. NIKU Oppdragsrapport 21/2016. Oslo: Norsk Institutt for Kulturminneforskning.

Martens, Jes. 1994. "Borremose - Refuge - Fortified Settlement - Central Place?” Ethnographisch-Archäologische Zeitschrift vol. 35, 1994-2: 241-276.

Martens, Jes. 2001. „Kraghede“. In Realleksikon der Germanischen Altertumskunde, (Hoops). Edited by Rosemarie Müller, Heinrich Beck, Dieter Geuenich, and Heiko Steuer, 2001;17: 281-6. Berlin, New York: Walter de Gruyter. 
Martens, Jes. 2006a. "Usynlige strukturer. Fosfatkartering af jernalderbopladser langs den skånske Vestkystbane”. In Järnålder vid Öresund, band 2, Metod och specialstudier. Skånska spår - arkeologi längs Västkustbanan, edited Anne Carlie, 48-109. Stockholm-Lund: Riksantikvarieämbetet, Avdelningen för arkeologiska undersökningar.

Martens, Jes. 2006b. "Dyrkningsspor i landskabet - materiale og metode”, In Järnålder vid Öresund, band 2, Metod och specialstudier. Skånska spår - arkeologi längs Västkustbanan, edited Anne Carlie, 176-213. Stockholm-Lund: Riksantikvarieämbetet, Avdelningen för arkeologiska undersökningar.

Martens, Jes. 2008. "På sporet af ældre jernalders agre i Skåne”. In Öresund - barriär eller bro? Kulturella kontakter och samhällsutveckling i Skåne och på Själland under järnåldern, edited by Anne Carlie. 189-207. Göteborg - Stockholm: Makadam förlag.

Martens, Jes. 2009. “Ny E18 gjennom Vestfold, Bommestad-Langåker, Forprosjekt”. In Arkeologiske undersøkelser 2003-2004, Varia 77, edited by Jostein Bergstøl: 22-23. Oslo: Kulturhistorisk museum, Universitetet i Oslo.

Martens, Jes. 2011. "Pre-Roman Iron Age Settlements in Southern Scandinavia”. In Haus - Gehöft - Weiler - Dorf. Siedlungen der Vorrömischen Eisenzeit im Nördlichen Mitteleuropa, edited by Michael Meyer: 229-250. Rahden/Westfalen: Verlag Marie Leidorf GmBH.

Martens, Jes, and Mads Ravn (editors). 2016. Pløyejord som kontekst. Nye utfordringer for forskning, forvaltning og formidling. Kristiansand: Portal forlag.

Nielsen, Viggo. 2010. Oldtidsagre i Danmark. Sjelland, Møn og Lolland-Falster. Jysk Arkæologisk Selskabs Skrifter 71. Aarhus: Jysk Arkæologisk Selskab.

Nielsen, Viggo, and Niels-Christian Clemmensen. 2015. Oldtidsagre i Danmark. Fyn og Langeland. Jysk Arkæologisk Selskabs Skrifter 86. Aarhus: Jysk Arkæologisk Selskab.

Nordin, Fredrik. 1886. "Gotlands s. k. kämpagrafvar 1-2”. Kungl. Vitterhets Historie och Antiquitets Akademiens Månadsblad 1886: 97-118, 145-174.

Nørlund, Poul. 1948. Trelleborg. Nordiske fortidsminder, Bd. IV-1. København: Gyldendal.

Olesen, Lis Helles, and Espen Schlosser Mauritsen. 2015. Luftfotoarkeologi i Danmark, Holstebro: Holstebro Museum.

Risbøl, Ole. 2009. "Fugleperspektiv på kulturminner. Bruk av flybåren laserskanning i arkeologien”. Viking 2009: 211-226.

Risbøl, Ole, Ole Martin Bollandsås, Anneli Nesbakken, Hans Ole Ørka, Erik Nesset, and Terje Gobakken. 2013. "Interpreting cultural remains in airborne laser scanning generated digital terrain models: effects of size and shape on detection success rates". Journal of Archaeological Science 40 (2013): 4688-4700. 
Shetelig, Haakon. 1909. “En ældre jernalders gaard paa Jæderen”. Bergen Museums Aarbog 1909: 1-18.

Stamnes, Arne, and Andersson Anderson. 2016. The Application of Geophysical Methods in Norwegian Archaeology. A study of the status, role and potential of geophysical Methods in Norwegian archaeological Research and Cultural Heritage management. Trondheim: NTNU.

Stenberger, Mårten. 1933. Öland under äldre järnåldern. Sockholm; Akademiens Förlag.

Svensson, Håkan, and Bengt Söderberg. 2009. "Dumpad kunskap?: om metallsökning och uppdragarkeologins villkor”. Fornvännen 2009-2: 131-136.

Sørensen, P. Harder. 1982. "The Use of Air Photographs in Celtic Field Studies”. Journal of Danish Archaeology vol. 1: 77-86.

Thrane, Henrik. 1985. "Gudmeproblemet og Gudmeundersøgelsen”. In Gudmeproblemer. Beretning fra et bebyggelsesarkcoologisk symposium på Hollufgård afholdt den 24. til 25. oktober 1984, Skrifter fra historisk institut, Odense Universitet, nr. 33, edited by Henrik Thrane: 4-9. Odense: Odense Universitet.

Voss, Olfert. 1960. "Når man ser det fra oven." Skalk 1960-2: 4-6.

\section{Rezumat}

Așezările epocii fierului (500 a. Chr.-1000 p. Chr.) din Danemarca și Scandinavia au fost cercetate în număr destul de mare, fiind vorba nu doar de complexe de locuit, ci și de structura gospodăriilor și a aşezărilor care sunt suficient de bine ilustrate. Deoarece acest lucru nu este la fel de bine pus la punct peste tot în Europa, lucrarea se focalizează asupra primului pas foarte important pentru a face față acestei probleme - prospectarea arheologică. Există o serie de metode și acestea funcționează cel mai bine în combinație. În timpul prospectării, arheologul trebuie să lucreze într-un mod critic, pentru a nu se limita doar la reproducerea faptelor deja cunoscute.

Cuvinte-cheie: cercetări de teren, arheologia așezărilor, abordarea critică a surselor, metode arheologice de teren.

Jes Martens ( $\mathrm{PhD}$ ), associate professor at the Museum of Cultural History of Oslo.Email: jes.martens@khm.uio.no 